\title{
The Traditional Symbolism of the Sun Dance Lodge among the Wind River Shoshoni
}

\author{
By ÅKE HULTKRANTZ
}

\section{Introductory remarks}

Of all the North American Indian religious ceremonies no one is as spectacular and as well-known as the Sun Dance of the Plains Indians ${ }^{1}$. The information collected on the subject since the turn of the century is quite extensive $^{2}$. However, while there is a mass of materials on the outer features of the Dance, on behavioural and ritual aspects, there is very little information on its religious aspects, in particular the meaning of the ritual. As F. Eggan has stated, "despite all the studies of the Sun Dance we still do not have an adequate account giving us the meaning and significance of the rituals for the participants and for the tribe. One such account would enable us to revalue the whole literature of the Sun Dance"s. Neither is there any thorough study of the religious symbolism of any Sun Dance, although for instance G. Dorsey's monograph on the Arapaho Sun Dance observes meticulously all pertinent details (Dorsey 1903) ${ }^{4}$.

The comparative studies of the Sun Dance dismiss the religious meaning of the Dance as unessential. The following pronouncement by such an authority as Robert Lowie is representative: the Sun Dance "does not revolve about the worship of a particular deity, the popular English name for it being a misnomer, but is a composite of largely unintegrated elements prominent in the area at large. The remarkable thing about it is the wide distribution of many objective features, while the interpretations and ostensible motives for holding it vary widely. [.. Y Yet] the alleged aims of the ceremony vary widely. We must infer that the ceremonial behavior in the festival was older and that the assumed objectives were subsequent additions. It is also clear that the Dance was only in part a religious ceremony and in large measure served for the aesthetic pleasure and entertainment of the spectators" 5 . In a characteristic way Lowie here loses sight

\footnotetext{
1 The English name, Sun Dance, is a misnomer. The gazing at the sun in the Sioux Sun Dance inspired this designation. The sun plays a role in some Sun Dances; as the Crow say, it is the "mask" of the Supreme Being. The basic import of the Sun Dance will be given below. Cf. also 57 .
}

${ }^{2}$ Cf. Hultkrantz 1967 a, 29 ff.

3 Eggan 757. Cf. also Hultkrantz 1965, 88; cf. the critical remarks, Jorgensen 177.

${ }^{4}$ For a forthcoming study on the Crow, cf. Miller Ms.

5 Lowie 1954, 178, 180. 
of the central perspective which joins all partakers of the Dance, the religious meaning which is the motive for its performance. This meaning may be different in different tribes, but it is there. When formulated by the dancers or believers it is as "objective" as any other ceremonial trait. Lowie's assumption that behaviour antedates objectives is just one of those behaviouristic clichés.

Lowie belonged to the team of anthropologists who seventy years ago noted down the Sun Dance ceremonials of the Plains tribes. His general views mirror the spirit in which these investigations were undertaken. It is obvious that the interest in the symbolism of the Dance ${ }^{6}$ was minimal among these anthropologists. A new effort to appreciate this symbolism at its intrinsic value is pressing. Such an effort is possible because the material that was salvaged is-in spite of all shortcomings in our documents -partly satisfactory for analysis. Moreover, many Sun Dances are still performed, and may thus be observed in the field ${ }^{7}$.

The following account is an attempt to view the religious symbolism of the Wind River Shoshoni Sun Dance lodge in a "meaningful" perspective. Attention is paid not only to the ideology of the Dance as such but also and foremost to the concrete elements of the Sun Dance structure which together throw further light on this ideology. A particular place in the analysis will be devoted to a new scholarly interpretation according to which the Shoshoni Sun Dance serves as a revitalization cult.

The investigation is mainly based on my own field research among the Wind River Shoshoni in Wyoming 1948-58. There is, however, additional material in printed works, such as ethnographical accounts by Lowie and Shimkin and a folkloristic book by Olden (Lowie 1919, Shimkin 1953, Olden 1923). Besides there are archival documents and other unprinted sources in public or private ownership to which I have had access. The value of these sources is very different. Some are tall tales, like Allen's impossible story of the ceremony of the Sheepeater Indians, a mountain branch of the Wyoming Shoshoni ${ }^{8}$. Others are most informative, as is (the Shoshoni) H. St. Clair's manuscript on the Dance (1902), published as an appendix to Shimkin's book ${ }^{9}$, or his kinsman L. St. Clair's manuscript from 1936 which he amended and corrected for me in 1948, four years before his death. St. Clair's information goes back to Judge Ute, a Shoshoni traditionalist who died in $1927^{10}$.

\footnotetext{
6 The word "dance" should not mislead: it expresses the dominant ritual action during the ceremony. Most Indian ceremonies are labelled "dances".

7 However, the new Indian secrecy as regards traditional religion prevents field observations in many places.

${ }^{8} \mathrm{Cf}$. Allen $9 \mathrm{f}$., $70 \mathrm{f}$,, and comments Hultkrantz 1970 a, $253 \mathrm{ff}$.
}

${ }^{9}$ Cf. Shimkin 1953, 474f. St. Clair was Lowie's chief informant on the Wind River Shoshoni. Cf. Lowie 1909, 169.

${ }_{10} \mathrm{Cf}$. the Fort Washakie: death records. F. Burnett, in a letter to Professor Hebard in 1929 , gives the year 1928, cf. Hebard 1933, 235. 
Our classic sources on the Plains Sun Dance have been presented in a "flat" perspective, that is, in the ethnographic present, regardless if the ceremony was celebrated at the time of recording or a hundred years earlier ${ }^{11}$. The Wind River Shoshoni symbolism as described here refers primarily to the traditional pattern of symbols at the time of my field visits, and secondarily to the Christian symbolism at the same time. Some twenty years ago the Christian symbolic interpretation seemed superficially to supersede the traditional one. It is however less certain that this is the situation today, considering the renaissance of traditional Indian values.

\section{The Plains Indian Sun Dance}

The Sun Dance is, beside the ubiquitous vision quest, the most typical exponent of Plains Indian religion ${ }^{12}$. It is closely tied up with the ancient way of life peculiar to these Indians: bison-hunting on horseback, living in movable tents (tipis), a tribal organization and graded war-societies. Whatever its antecedents--there are indications that it sprang forth in old archaic society-the Sun Dance as we know it from historical records was formed inside the dynamic Plains culture that emerged in the early XVIIIth century. It became so firmly settled that it survived the downfall of the independent Plains socio-political organization and the abolition of the Plains Indian economy at the end of the last century.

Analysis of the distribution of Sun Dance traits convinced Leslie Spier that the Dance had originated among, or diffused from, the Arapaho, Cheyenne and Teton Dakota ${ }^{13}$. Perhaps it would be more cautious to say that the Plains form of the ceremony was modelled in these societies (for it seems to belong to a widespread cultic complex). The Dakota Dance was closely knit up with the military complex of the Plains Indians, whereas the Arapaho and Cheyenne Sun Dances strongly elaborated the religious import: the Dance as a cultic drama, a re-creation of the primeval action through which the earth was once created ${ }^{14}$. Now, this religious idea is manifested in ritual and symbolic details in most Sun Dances all over the Plains area, but is not always clearly recognized as such. The war complex ideology, for instance, often seems to have taken over, several recurrent features having a direct association with warfare. After the eclipse of the Plains military pattern a hundred years ago the Sun Dance scene sometimes turned into an arena for the cure of diseases-a hypertrophy of a trait that had originally been subsumed under the re-creation aspect.

I am anxious to point out that this reconstruction is not in line with the opinion of many of my American colleagues (cf. Lowie, above). It is however perfectly in harmony with the main tendencies in W. Schmidt's

11 Cf. Hultkrantz 1967, 102.

12 Cf. Wissler 1950, 222.

13 Cf. Spier 477, 491, 494 f., 498.
14 Cf. Hultkrantz 1973, $9 \mathrm{ff}$. , and sources quoted there. 
and W. Müller's interpretations ${ }^{15}$, and it backs up Eliade's view of the meaning of ritual drama ${ }^{16}$.

As a New Year ceremony the Sun Dance was originally held in June when a fresh new verdure covered the ground. A typical Sun Dance like the one arranged by the southern Arapaho contains the following elements (Dorsey $1903)^{17}$ :

The man who has made the vow or been blessed by a dream (vision) to set up a Sun Dance, and the military society to which he belongs, prepare the tribe for the ceremony and select the time and place. When time is up the different bands come together, and their tipis form a big circle with the opening to the east, the sacred direction.

During four days of preparation the candidates of the ceremony are assembled in the so-called White Rabbit lodge, a tipi which has been erected to the west of the middle point of the big camp circle. Here a new fire is kindled, the sacred fetishes (a sacred wheel, a buffalo skull) are brought in, and the candidates rehearse the songs and rituals pertaining to the ceremony.

Renowned warriors from military societies, equipped with horses, lances and guns charge on a particularly selected cottonwood tree, shoot at it and make coup on it (i.e., touch it with their hand or a staff in order to count a point of honour). After prayers to the tree some other soldiers cut it down. It is dragged to the Sun Dance circle, but before reaching camp it is attacked by members of other societies in a sham battle. The latter ends with the victory of the pole-dragging soldiers. The tree is then ceremonially raised in the centre of the dance ground. Other poles are attached to the tree as roof poles, peripheral uprights and cross-pieces, and the walls are covered with willow brush. The result is an airy, circular structure with a big opening towards east. It stands ready on the fourth day, and at the same time the Rabbit tipi is taken down.

In the evening of the same day the dancers enter the Sun Dance lodge in their ceremonial outfits. For three days and three nights they fast, dance (periodically) in front of the centre pole and pray to the powers. In the early mornings they perform the "sunrise dance". The body-paint of the dancers is changed each day by the "grandfathers", or personal advisors of the dancers. The first day after the "dancing in" an altar is built on the west side of the centre pole. It is formed by prairie sods representing the first ground in the creation myth and by the buffalo skull and sacred wheel mentioned before and a ceremonial pipe, among other items. The next day is "medicine day" when the dancers might receive visions from the powers above. This day there is also a display of supernatural power,

15 Cf. Schmidt 811 ff., Müller 1956, $303 \mathrm{ff}$. Cf. also Underhill 151: the development of a basic firstfruits rite.
16 Cf. e.g. Eliade $51 \mathrm{ff}$.

17 Cf. the summary Hultkrantz 1973, $11 \mathrm{ff}$. 
and curing of the sick. On the final day each dancer may have a sip out of a bucket containing water from "the great lake in the sky". In the evening there is a great feast. The ceremony ends the next morning.

Some tribes, like the Teton Dakota and the Blackfoot, practised selftorture in their dancing in the past. The aim was to call on the powers and ask for their pity. Recently these tribes have resumed their mortifications.

\section{The Wind River Shoshoni Dance: history and phenomenology}

The Sun Dance that is performed among the Wind River Shoshoni differs in some respects from the Arapaho Sun Dance, just as both differ from other Plains Sun Dances in ritual details and symbolism. The Shoshoni Dance is clearly marginal to other Sun Dances, in this respect reflecting the peripheral location of the Shoshoni on the Plains ${ }^{18}$. It has moreover changed with time, depending primarily upon three factors: the re-creating force that may be attributed to visions, influences from other Sun Dances, and, in later times, pressure from the European civilization resulting in an increasing adoption of white (Christian) values.

Everything seems to indicate that the Wind River Shoshoni Sun Dance is of comparatively recent origin ${ }^{19}$. It had however a predecessor of considerable age, a round-dance called the "Father Dance" (apönökar), possibly also the "Thanksgiving Dance"20. In this Dance which continued until recently the people came together and shuffled around a cedar tree, while they thanked the Supreme Being (tam apö, "our father") for his gifts and asked him for bounty in the year to come. Similar prayer dances have existed among the Shoshoni and Paiute of the Basin area ${ }^{21}$.

Although the Father Dance and the Sun Dance have occurred independently of each other, some elements of the former could have found their way into the Sun Dance. According to my informants a round-dance formerly took place inside or outside the Sun Dance lodge after the end of the regular Sun Dance ceremonies; some people found this being less proper, however. Informant L. St. Clair, an excellent historian, considered the preliminary dancing before a shelter (cf. below) a left-over of an original "Sun Dance". This seems however less probable.

The beginnings of the Shoshoni Sun Dance are veiled in mystery. Indeed, the Dance escaped the attention of the explorers of the last century.

${ }^{18}$ Cf. Shimkin $1953,408$.

${ }^{19}$ I leave aside here the whole problem of the relationship, if there ever was one, between the archaeological remains of the Medicine Wheel on Bald Mountain in the Big Horn range, other medicine wheels of the area and the ancient Sun Dance. Early on there was the idea among the whites that some sort of connection existed between medicine wheels and Shoshoni religion. Cf. Comstock in Jones 265. However, knowledgeable Shoshoni Indians refer the wheels to the Crow. ${ }^{20}$ Cf. Olden $37 \mathrm{f}$., Lowie 1915, 817, Shimkin 1953, 433 f. and Thompson Ms.

${ }^{21}$ Cf. Hultkrantz s.a., Mythology. 
Colonel Brackett's paper on the Shoshoni from 1879 does not mention it, which however may be due to his limited knowledge ${ }^{22}$. H. St. Clair's manuscript from 1902 is the first authentic description ${ }^{23}$. As to the age of the Dance Robert and Yolanda Murphy seem to infer that it appeared only with the early reservation period ${ }^{24}$. Grace Raymond Hebard held the opinion that the Dance was brought to the Shoshoni by the famous Sacajawea, the pilot of Lewis and Clark, when she returned from the Comanche in 1843 , for some of her descendants claimed she was the introducer of the Dance ${ }^{25}$. Shimkin, again, basing his conclusions on the evidence of old informants and archival data, establishes the years $1800-1820$ as the probable date of the introduction of the Sun Dance ${ }^{26}$. My own field information and research in old documents confirms his results. Moreover, I think a forgotten notice by J. Beckwourth on "the medicine lodge" in the Shoshoni camp at Weber River in 1825 refers to the Sun Dance ${ }^{27}$.

The man who brought the Sun Dance to the Shoshoni was apparently Ohamagweia, or Yellow Hand, a Shoshoni chief who was by birth a Comanche, and who in one or another way was related to Sacajawea ${ }^{28}$. It was probably an old Kiowa or Comanche form of the Dance that was introduced ${ }^{29}$. Certainly, there is also another Shoshoni tradition according to which the Shoshoni Dance antedates all other Sun Dances ${ }^{30}$. This version is however more a testimony of pious belief than a record of historical facts. Yellow Hand is said by many people to have received the Dance in a vision, and several versions of this vision have circulated on the reservation.

We do not know for sure the outlines of the original Shoshoni Dance, although Shimkin has tried to reconstruct $\mathrm{it}^{31}$. So much is certain that in the main it followed the general Plains pattern as illustrated here with the Arapaho Dance. It also showed some peculiarities of its own. Thus, elderly

22 He writes, for instance, "Material pleasures alone are those which a Shoshoni understands." Cf. Brackett 331.

23 It has since been printed in Shimkin 1953 , $474 \mathrm{f}$.

24 Cf. Murphy 308.

25 Cf. Hebard 1933, 157, 201, 259f., 275. The date for Sacajawea's arrival is not certain, and her role in the Sun Dance history is doubtful. Cf. Shimkin 1953, 410f.; Hultkrantz 1975, 154.

26 Cf. Shimkin 1953, 413. There is in the agency files a copy of a letter (June 15, 1937) from Mr. F. Stone, superintendent, in which he gives the date "about the year 1819" for the first Sun Dance. He does not say how he arrived at this date.

27 Cf. Life $61 \mathrm{f}$; cf. Hultkrantz 1968, $297 \mathrm{f}$., 302. According to Beckwourth the ceremony took place in the winter season. However, this is in agreement with what some informants have to tell, cf. below.

${ }^{28}$ This relationship was in my view different from the one postulated by Shimkin, cf. Hultkrantz 1968, 294f., 296 n. 17. On Ohamagweia as introducer of the Dance, cf. Shimkin 1953, $409 \mathrm{ff}$; Hultkrantz 1968, 294, $301 \mathrm{f}$.

29 I follow here Shimkin's interpretation, Shimkin 1953, $414 \mathrm{ff}$.

${ }^{30}$ St. Clair Ms.: "The first Indians to dance the Sun Dance were the Shoshone Indians. This Sun Dance was founded by a Shoshone Indian." Other Shoshoni Indians corroborated this "information", and one of them asserted that the Shoshoni had exported the Dance to the Arapaho, Sioux and other Indians.

31 Cf. Shimkin 1953, $417 \mathrm{ff}$. 
informants could still in the 1940 s tell us that the Sun Dance was also formerly celebrated in wintertime ${ }^{32}$.

The general motives for the Dance to be arranged were wishes for a long life and good luck in general, and particularly success in war and cure for disease ${ }^{33}$. It is difficult to judge if these goals were collectivistic, aiming at the tribe as a whole, or individualistic. In any case, they were expressed in the ceremony leader's prayer before the centre pole immediately prior to the beginning of the dancing. The centre pole was adorned with a buffalo skull, facing west, an eagle in a nest of willows and a small "Sun Dance doll" made from wood or buckskin. On the other hand, there was no altar and no buffalo skull at the foot of the pole. During the four nights prior to the proper ceremony the leader and a few other participants practised Sun Dance songs at a particular windbreak erected for the purpose. The lodge ceremony then started in the evening and lasted three nights and days ${ }^{34}$. The dancers jogged steadily up and down looking upon the centre post and its sacred images. Occasionally they also danced up to the centre pole. On the second full day relatives helped to construct a small booth around the place where the dancer lay down to rest, just behind his dancing position. The skin of the booth was, according to Shimkin, painted with "records of visions of war experiences" 35 ; I have no such information. An interesting detail is that when the dancers received a sip from the sacred water (the event that marked the termination of the Dance) they vomited ${ }^{36}$. Such vomiting occurred also in the Arapaho and Cheyenne Dances. One is furthermore reminded of the sacred vomiting in the New Year rituals of the Southeastern Indians.

The great change in the Sun Dance occurred around 1890 when the Shoshoni had adapted themselves to reservation life, buffalo hunting and warfare was gone and the old religion was on the verge of becoming suppressed by the white rulers and the Christian missions. Ritual traits referring to war disappeared to a large extent, and the emphasis on blessings for success in war was replaced by prayers for good health and cure from disease. The new political organization with a tribal council (1893) instead of chieftainship and informal meetings was reflected in the creation of a Sun Dance committee. The date of the Dance was postponed from June to late July, the time when the harvest had been taken care of. Some old traits like the putting up of a Sun Dance doll and the vomiting went out

32 Cf. Hultkrantz 1968, 302. My chief informant here, Nadzaip (a medicine-woman), had a brother, Morgan Moon, whose innovations as a Sun Dance leader-due to his visionary experiences-created strong counter-reactions among the Shoshoni. Cf. Shimkin 1953, $435 \mathrm{f}$.

${ }^{33} \mathrm{Cf}$. Shimkin 1953, 431 .
34 The number three is sacred west of the Rocky Mountains, the number four east of them; the Wind River Shoshoni having geographically an intermediate position keep both numbers sacred.

35 Shimkin $1953,425$.

36 Cf. also Olden 36; Fremont 9. 
of use, at least temporarily, whilst others, such as the dancing up to the centre pole, became more common. Influences from other Sun Dancesparticularly from the one of their eastern neighbours, the northern Arapaho, who in the 1870 s had settled on the reservation-resulted in some new ritual elements. The most conspicuous change, however, was the reinterpretation of the Sun Dance symbolism into Christian concepts ${ }^{37}$.

The reformulation of the Sun Dance in the 1880s and 1890s, and the new emphasis on health and curing, saved the Shoshoni Dance in a time when the old hunting life was gone, most Sun Dance ceremonies were forbidden by white authorities and several of them-in particular among the tribes practising torture in their Dance-became extinct. Indeed, it was during this difficult time that the Wind River Shoshoni version of the Sun Dance spread to the northern Ute (1890), the Fort Hall Shoshoni and Bannock (1901), and the Shoshoni of Nevada $(1933)^{38}$.

After the Indian Reorganization Act (1934) there was a new resurge of Sun Dance celebration on the Wind River Reservation ${ }^{39}$. More people than ever before took part in the Sun Dance. Since the Sun Dance was now mainly a means of achieving spiritual power-which in the old days could only be procured on solitary vision-quest expeditions-and a ritual for the removal of disease, and therefore its presumably old interpretation of a New Year's rite had become vague and even obsolete, it was possible to arrange several Sun Dances each summer ${ }^{40}$. For instance, one Dance is usually arranged by conservative believers, another by peyotists. The latter deviate from other sun dancers in not expecting visions of supernatural power during the Dance, and in wearing a pouch with a Peyote button around the neck.

One of the renewers of the Sun Dance in recent times has been the famous medicine-man John Trehero, now in his nineties (and no longer active). Being a descendant of Yellow Hand he reintroduced the Sun Dance doll for the ceremonies in which he or his close kinsmen took part. He also transferred the Shoshoni Dance to the Crow Indians $(1941)^{41}$.

The 1950s brought tendencies of commercialization into the Sun Dance celebration. However, the sacred character was not lost and has since been strenthened under the pressure of resurging Indian nationalism.

Looking back we may say that in modern times the Shoshoni Sun Dance has absorbed almost all expressions of earlier religious rituals, in particular the vision complex and the "shamanism" 42 . With a certain justification we

${ }^{37}$ Cf. Hultkrantz 1969, 22, 33, $36 \mathrm{ff}$.

${ }_{38} \mathrm{Cf}$. Jorgensen $19 \mathrm{ff}$., $25 \mathrm{f}$;; Hoebel $578 \mathrm{f}$.

${ }^{39}$ Cf. Hultkrantz 1969, 34.

40 This notwithstanding I was informed, during my visit to the Stoney (Assiniboin) of Alberta in the autumn of 1977, that these Indians had held six Sun Dances that summer.

${ }^{41}$ See Voget 1948, $634 \mathrm{ff}$. There is testimony that, in spite of Shimkin's denial, dolls had been used in the time between the two World Wars by Sun Dance leaders Andrew Bazil and Morgan Moon.

${ }^{42}$ In Shimkin's words, the Sun Dance is "going far in socializing shamanism." Cf. Shimkin Ms., 9. 
may consider the Sun Dance as the aboriginal religion of today. As such it is the core of Shoshoni traditionalism, and the ideological centre of ethnic cohesion.

\section{Shoshoni Sun-Dance ideology and the revitalization theory}

The foregoing reconstruction of the Wind River Shoshoni Sun Dance presupposes continuity in patterns and ideas up to our own time. This interpretation has recently been challenged by $\mathbb{J}$. Jorgensen in a provocative book, The Sun Dance Religion. He suggests that the modern vigorous Sun Dance among the Ute and Shoshoni (which both belong to the Numicspeaking peripheral Plains and Basin groups) constitutes a so-called redemptive movement, and thus has little connection with the old Sun Dance. He puts this new "Sun Dance religion", as he calls it, on a par with nativistic, contra-acculturative movernents (although he refuses to use a term like acculturation).

Jorgensen points out that the main motivations for the Dance are an oppressed population's need for health and happiness in a white-dominated world, and for tribal coherence against white power, furthermore the single individual's need for personal status and esteem within his community ${ }^{43}$. It is the ritual participant's conscious intention to gain supernatural power in the Dance. He does it in order to forward his own health, or that of others, or to help those who are mourning by injecting into them resources from the power-filled ceremony. If possible he also tries to become a medicine-man through visions during the Dance ${ }^{44}$. In Jorgensen's view the Shoshoni Sun Dance is not just a ceremony, it is the nucleus of a religious movement, a Sun Dance religion. He adopts the view that in the 1880 s, "at a time when the Wind Rivers had lost access to the strategic resources on which they once subsisted, when their movements were restricted, and when their death rate greatly outstripped their birth rate, a few Wind River shamans began to retool the Sun Dance ritual" ${ }^{45}$. There was a change in focus from hunting and warfare to curing of illness and maintenance of communal unity, and "a few Shoshone shamans sought a solution to the illness, death, and petty factionalism that became pervasive in the $1870 \mathrm{~s}$ and 1880s" 46 . Thus, the Sun Dance was reworked and crystallized into a redemptive movement ${ }^{47}$.

Jorgensen observes that the restructuring of the Sun Dance took place when the people had lost faith in another revitalization movement, the Ghost Dance. Using D. Aberle's terminology he states that when the transformative movement the Ghost Dance failed, people turned to a redemptive movement, the new Sun Dance. According to Aberle a transformative

\footnotetext{
${ }^{43}$ Cf. Jorgensen $234 \mathrm{ff}$., $244,246 \mathrm{ff}$.

${ }^{44}$ Cf. ib. 247.

45 Ib. 18.
} 
movement seeks total change of social or natural order, whilst a redemptive movement seeks total change of the individual ${ }^{48}$. It stands to reason that in North America a movement of the latter kind should be more successful during reservation time. The Sun Dance "religion" has persisted for almost a century and will, in Jorgensen's view, continue to persist.

Is Jorgensen's picture correct? His description of the changes about 1890 are certainly to the point: this was the time when Christian symbolism began to be accepted, when references to war and hunting were dampened down and problems of tribal cohesion and, in particular, concerns of health took precedence in prayers and rituals. The gradual reduction of other ritual complexes, such as the vision quest, have given a strengthened importance to the Dance, and perhaps the visions received in the Dance. Thus the Sun Dance has become the focus of Shoshoni religious life, an observation that I was able to make during my field research ${ }^{49}$.

However, I do not agree with Jorgensen when he defines this modified Sun Dance as a redemptive movement in the sense referred to. In the minds of the participants this "western form" of the Sun Dance is not separated from other Sun Dances. Nor is it alien to other Plains tribes, and it attracts visitors from these peoples. The Shoshoni are conscious of its supposed origin in a very ancient time, and the procedures follow basically the old Sun Dance pattern. The Sun Dance is not considered a separate "religion", but part of the old religion. At the most we may say that the old religion has been condensed into a "Sun Dance religion"so.

If my reasoning here is correct, as I think it is, the present leaders of the Sun Dance would still today cling to a traditional, possibly cosmological interpretation of the ceremony. In the following I shall try to demonstrate that this is the case to a large extent, through three consecutive operations:

a) an investigation of Shoshoni opinion on the meaning of the Sun Dance;

b) an analysis of traditional symbolism of the cultic lodge; and

c) a short examination of the nature and function of Christian symbolism attached to the Sun Dance lodge.

\section{The meaning of the Sun Dance}

As has emerged from the foregoing the manifest meaning of the Sun Dance has changed considerably over the generations. Still, due to the conservatism of religious thought it should be possible to reveal some very old tenets still held by practitioners. The investigator has to be aware of the fact that the Shoshoni generally confuse the meaning of the Dance with the motives behind the arrangement of individual Dances or the joining in the Dance by individual believers.

${ }^{48} \mathrm{Cf}$. Aberle $318 \mathrm{ff}$.

49 Cf. Hultkrantz 1969, 27, 33.
${ }^{50}$ I used this expression in Hultkrantz 1969 , 22. 
The presumably original existential interpretation turns up occasionally. Said informant L.S.C. ${ }^{51}$, "we dance the Sun Dance so that we may live during the winter, survive it and manage to live until next summer, when we have a new Sun Dance." The same informant also said that people pray "for strength, happiness, many animals to kill, berries and roots and good health and happiness for the people." Or as J.T. put it, he hoped for good spiritual gifts in the days to come. Closely connected with prayers for the future is the thanksgiving for past blessings. For instance, when at the sunrise rite the dancers face the east they thank the Supreme Being for the sun and its light and for the life that he bestows on the earth (L.S.C.). J.T. felt good when his grandson returned unhurt from Korea. God was good, and he wanted to thank him by sponsoring a Sun Dance for the people; "I could not thank God in any other way."

It is a common observation today, also conceded by an idealist like L.S.C., that all Shoshoni have different views of what the Sun Dance stands for ${ }^{52}$. L.S.C. could even see that "people enjoy meeting, it always makes you glad to see your friend and relative." He was quite aware that many interpretations are possible. Foremost among them all he stressed the curative aspect ${ }^{53}$. According to him the buffalo spirit of the inauguration vision ${ }^{54}$ said the following to the hero who was granted the message to set up the first Sun Dance: "Our Father on high sent me to you to tell you that a certain power will be imparted to you. It will enable you to cure those who are sick. You may cure any sickness by faith and prayer. I shall give you that power. [...] When you have gone through [the Dance] the power will help you to extract those agents that make people sick." Other informants (T.R., P.C. and others) agreed that this was the chief message of the Sun Dance. One of medicine-man J.T.:s guardian spirits once urged its client to go into the Sun Dance and pray with the other dancers for the sick.

Some other interpretations are also given, probably spoils from the once more comprehensive program and import of the Dance. There is still a vague remembrance that the Sun Dance gives divinatory visions of war.

\footnotetext{
${ }^{51}$ In the following the informants will be rendered by their initial letters. Two main informants who have already been mentioned are John Trehero (J.T.) and L. Clair (L.S.C.). Of these Clair (1903-1952) was my foremost informant on the symbolism of the Sun Dance. He had, as I have indicated, written an account of the Sun Dance which however, deviated in part from what he told me. $\mathrm{He}$ explained that this was due to his reticence to present the true facts in the manuscript. Lynn had received his information from the knowledgeable old-timer Judge Ute, or Yutatsi (1843-1927).
}

${ }^{52}$ In her unpublished notes Miss Marion Roberts states that all dancers have different reasons for going into the Dance: some think they will recover from illness, others ask for a good harvest, and still others go in for renown. Roberts, Marion, Ms.

${ }_{53} \mathrm{Cf}$. also St. Clair Ms.

${ }^{54}$ L.S.C., quoting Ute (see above), embraced the tradition that the Sun Dance was first entrusted to the Shoshoni by a buffalo spirit. This tradition is at variance with another tradition according to which Yellow Hand dreamt about a human spirit he had seen as a white man in a picture. 
L.S.C. told me that in the old days a person who fainted from exhaustion in the Dance was covered with a buffalo robe. When he came to he vomited white horsehair, for instance-a sure sign that the people would win a battle and catch a white horse from the enemy, or make a coup on that horse. Several features of the old ceremony indicated that it was once coupled with military purposes, such as the formal "killing" of the tree selected to become the centre post, the singing of a war song in front of the centre post during the Dance by a woman or an old man, and the firebringers' songs about their stealing horses from the enemy. These rites are of course now obsolete. However, wars are still topical. T.W. put up a Sun Dance in 1948 because some young Shoshoni had been drafted for military service, and he feared there would be a new war. He wanted the boys to be safe and out of danger, so he prayed for them.

Another motive for arranging or joining a Sun Dance is to attain supernatural power. Nobody prays for such power, as one does in the vision quest; if it comes, this is coincidental (L.S.C.). When in 1955 T.R. found that he recently had had bad luck and made bad medicine he decided to put up next year's Sun Dance; this way he thought he could bring about a change for the better. Many medicine-men use their powers in the Sun Dance, either in curing people, or prophesying or calling forth a soothing rain. Some are granted such power in the visions they receive during the Dance.

My chief informant on the Sun Dance and its ideology, L.S.C., made a remarkable connection between the Dance and Shoshoni eschatology. "If," he said, "I believe in the Sun Dance and go in and believe that I shall be free from my sickness, then I shall recover. If I am a good Indian and pray to the Father to help me, I have a straight road to walk after death. However, if I do not believe in the Sun Dance, and I live a no good life, I shall walk the other road and do not come to the Father." It is easy to see Christian reminiscences in this pronouncement. However, the double path of afterlife has a definite association to the old symbolism of the centre post, as we shall soon see.

It is, as we observed, necessary to make a distinction between the ideological frame, or meaning, of the Sun Dance and the causes (motives) of joining it or putting it up. Too often the issues are confused by the Shoshoni, as in the cases of T.R. and T.W., related above. In a few instances they are kept distinct, in most cases only individual motives are given. For instance, the sponsor of the Sun Dance in 1955, J.T., was urged in a vision to arrange it, no reason being provided. "I dreamt this year", said J.T., "that the eagle wanted me to put up the Sun Dance, for three nights and three days, for all my people [...]. The spirit pointed out to me the place of the Sun Dance lodge." Such a commandment has, certainly, some interior meaning, but it is hidden for human beings. The spirits have their reasons which man cannot grasp. 
All the variety of interpretations which have been reproduced here indicate that the meaning of the Sun Dance, vaguely perceived in some statements, is mostly obscured behind individual motives (which may be considered to represent parts of this meaning). It is furthermore obvious that, although the Shoshoni may be aware of a cosmic symbolism in their Sun Dance, the idea of a cyclic renewal as a re-creation of the world is not present in their thoughts. We have to keep this in mind when the account now turns to the symbolism of the Sun Dance lodge and its particulars.

\section{Cultic symbolism}

In the following presentation only such cultic objects as I found associated with the Sun Dance lodge will be referred to. Thus, the heap of stones and the digging-stick, mentioned by Shimkin, will not be discussed. The main symbolic parts of the lodge are demonstrated in the adjoining drawing ${ }^{55}$.

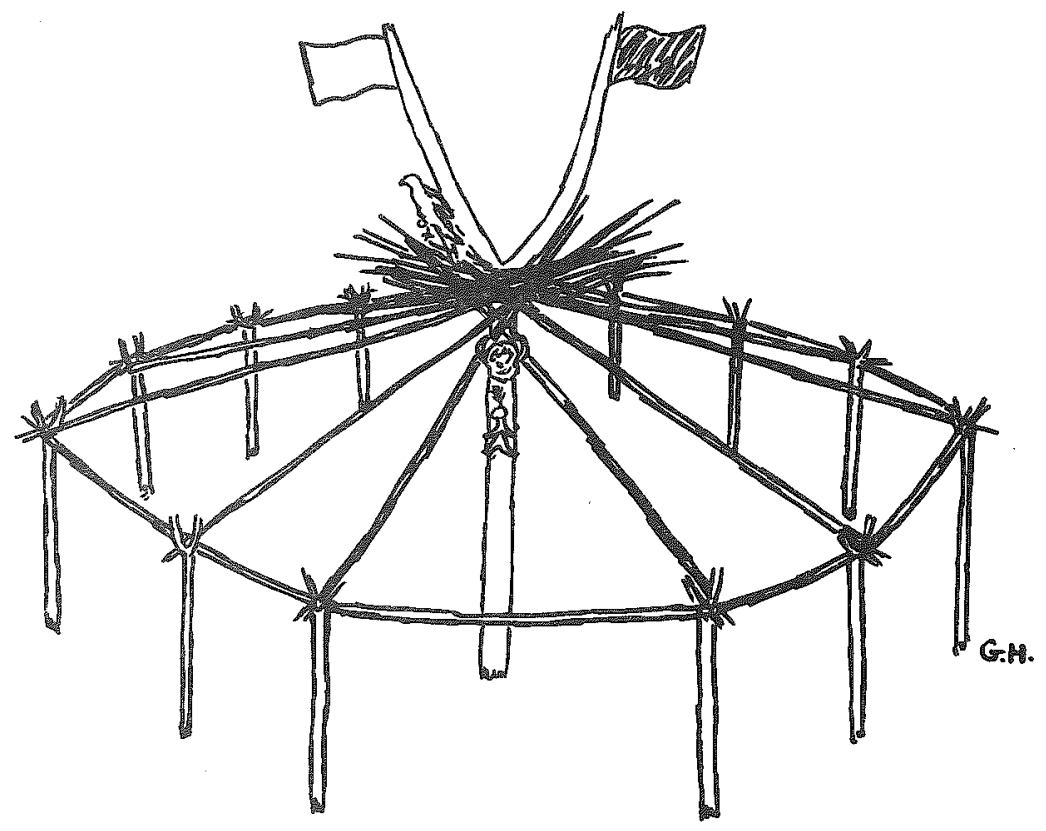

Diagram of a Wind Fiver Shoshoni sun Dance lodge.

6.1. The Dance lodge. The Dance lodge is called taguwunexa, "thirststanding-lodge", or taguwunögani, "thirst-standing-house"; taguwunö, or thirst-standing, being the name of the Sun Dance. The name thus refers to the physical exertion, not to the sacred import of the lodge.

55 For pictures of the Shoshoni Sun Dance, cf. Shimkin 1953, pl. 30-37; Hultkrantz 1973, pl. XVII-XXV. 
This does not mean to say that the lodge is not sacred. "The Sun Dance lodge is a symbol of the world," said L.S.C. "It is round because it is the world ${ }^{56}$. The rafters are supposed to extend over the earth. It is the first place where the humans could pray." Here is the original idea of the lodge as a microcosmos, a sacred replica of the earth or the world, clearly expressed.

Those who take part in the preparation dance-which is sometimes performed at the place where the dancing lodge will be erected- "dance to make the ground sacred place." "After the last preliminary night's singing the ground of the Sun Dance lodge is sacred ground" (L.S.C.). This means that in principle only the dancers are allowed in the section of the lodge where dancing takes place; not even a reputed medicine-man is supposed to be there unless he is one of the dancers. Outsiders coming in to receive blessings from dancing medicine-men are often requested to take off their moccasins and, if men, their hats. Women in the process of menstruation and men who are drunk have to keep away from the lodge. L.S.C. was most upset when after a Sun Dance in 1948 mounted youths played around inside the lodge.

The normal procedure is that the lodge rots away, or that its timbers are sold to interested buyers, whites and half-breeds. This is a new custom, said N., but "it spoils the medicine": diseases return to those who have been cured during the dance. However, even today the central pole is left to decay.

6.2. The centre pole. The middle post, or "forked pole" (wurušagar), is the most sacred part of the lodge. Ideally it should be a cottonwood tree which is quite juicy when green; however, nowadays also a pinetree may be chosen, for cottonwood grows sixteen miles up the river, whereas pine is available up in the foothills. A cottonwood centre pole "is always cool, however much the sun shines on it; this is not the case with common cottonwood trees" (L.S.C.). Stories circulate that during the Dance the centre pole opens, and water comes out. It is spiritual water that blesses the dancers but only can be seen by some. Dancers may drink it through their whistles.

These wonderful qualities of the centre post, as well as the ceremonial felling of the tree, the shambattle around it and the circumstantial ritual at its raising, testify to its symbolic importance. N. told me that the centre pole "from way back, when the Sun Dance was given to my people," was a vehicle for prayers. "The Father above told us that we must not destroy this pole, it should be left standing to decay naturally, for all the prayers and the ailments of the sick who attended the Dance still remain on this

56 The Indians represent the earth as a round disc. Cf. also Müller 1970, $203 \mathrm{ff}$. (Sioux Indians). 
pole." However, my informants were careful to point out that the prayers were not directed to the centre pole as such, just as they were not meant for the sun ${ }^{57}$. The pole thus serves as an intermediary between man and God. Sacred power emanates from the pole. L.S.C. admonished me to observe how the medicine-man J.B., when attending to the sick in the Dance, first stroked his medicine-feathers against the centre post before he made them touch his patients.

It is obvious that the centre pole, besides being a communication channel for prayers, represents divine power. "Many sun dancers pray before the centre pole, for it stands for Christ. Before this was done they prayed there nevertheless, for it stood for Our Father above," said G.W., a man in his thirtees in 1948. Chief Dick Washakie told Grace Hebard in 1926 that the cottonwood tree of the Sun Dance hall represented God ${ }^{58}$. L.S.C.:s opinion was that this forked pole "is a sign for the Milky Way. The Milky Way is believed to be a great path over which travel the people who have passed to the beyond" 59 . Thus, the centre pole has the function of being a replica of God and of the "backbone of the sky," as the Shoshoni call the Milky Way (tugungu:himp). The cosmic associations are obvious. The centre, God, the Milky Way, the communication channel-this is the world pole, the axis mundi and the road to God and the powers above.

In this light the very last ritual gesture becomes understandable. When the Dance is over the dancers throw their aprons at the foot of the centre pole, and some of the spectators tie on some pieces of clothing, and also tobacco or feathers, to the pole. In the old days, N. told me, the centre pole was sometimes covered with the clothing of the participants and their relatives. They should obviously be interpreted as prayers to the Supreme Being, a kind of communicative offerings. $N$. informed me further that the supplicant first made a prayer to God, and then placed a dress or a blanket a's an offering. The custom seems to be the same today. J.T. said that anybody who is sick-not necessarily a dancer-could "throw away [witein] his disease" by laying down his clothes by the pole. The disease would, he meant, dwindle away with the clothes. On the plain outside of Fort Washakie one can still observe those lonely forked poles with clothing attached to them, the last remnants of a Sun Dance celebrated months or perhaps years before.

${ }^{57}$ Cf. L.S.C.: "The dancers pray to God to bless them through the centre pole. But I have never heard anybody pray to the centre pole or the sun; they always pray to Our Father."

${ }^{58}$ Chief Dick Washakie was the son of old Chief Washakie, the last tribal chief (Hebard 1930, 294).

59 St. Clair Ms. L.S.C. explained to me that from the fork there is a bad path to the left, and a good one to the right, and in the Sun Dance you should ask God to be admitted to walk the right path. This echoes Christian teaching. However, the idea of a road of the dead which is plit in two, one for those who embraced the tribe's values and conformed to the $m$ in their lives, and one for those who lived unworthy lives and are excluded from the community in afterlife, is known from many parts of North America. 
6.3. The buffalo head. A head of buffalo, kwï, is fixed on the centre pole just where the forked branches come together, or slightly below. It faces west and is the centre of attention during dancing. In the old days it was painted with white clay, and sweet sage was put into its nostrils (L.S.C.). The latter custom is still extant. Another old custom, counting coup on the buffalo head by an old man before it was put in place (L.S.C.), has become obsolete.

The symbolism of the buffalo head was explained in the following way by L.S.C.: The buffalo represents the buffalo spirit of the founding vision, "the first message"; the sweet sage in its nostrils is "the symbol of the vapor" of this spirit, for "that had the smell of sweet sage." Also, the buffalo on the pole stands for food and nourishment. J.T. made the following statement: "The buffalo was created here on earth for food. He is the biggest eatable animal that has a split hoof. And all animals that have a foot like the buffalo are eatable. For that reason he represents the eatable animals on the pole." Several dancers who have been staring at the buffalo head while dancing during the potent second day, the day of visions, have experienced how the buffalo head moves, its eyes roll violently and steam stands around its nostrils. Such signs predict a vision, perhaps of the buffalo spirit itself.

The stuffed buffalo head has replaced the buffalo skull of earlier days, but the symbolism is apparently the same. It represents the most important economic resource of the heyday of Plains culture, when enormous bison herds strolled over the grounds. Its association with a ceremony that means the rejuvenation of all Nature's resources is therefore natural. If the spirit that revealed the ceremony to the people had the form of a buffalo this points to the importance the buffalo had in comparison to other animals. Indeed, there are hints that the buffalo spirit was a kind of a master of the game in Plains Indian ideology. "He is the chief of all animals," said the well-informed L.S.C. ${ }^{60}$.

6.4. The willows. A bunch of willows $\left(\operatorname{sih} \ddot{o}^{w i}\right)$ or grass is attached to the fork of the centre pole. I heard that in former days the buffalo skull should have been fastened over this bunch, but I have only seen Sun Dances where the buffalo head was placed under the willows ${ }^{61}$. It seems more reasonable to imagine that the eagle (cf. below) had the willows as its nest, as was the case among other Plains Indians.

The willows are tied in such a way that the ends point south and north ${ }^{62}$. I do not know if this arrangement has any symbolic implication.

According to L.S.C. the willows are symbols of the growing food ${ }^{63}$. They

60 Cf. Hultkrantz 1961, $208 \mathrm{f}$, 216.

${ }^{61}$ Cf. D. Washakie in Hebard 1930, 294.

${ }^{62}$ St. Clair Ms.

63 The willows that are shaken by the female choir seated close to the drummers left of the lodge entrance have the same symbolism. "It is the women's task to pick berries and roots," said L.S.C., "and the shaking of the willows is a prayer of much vegetational food." 
have been produced by Mother Earth. They stand for "the branches carrying nourishment for the living." L.S.C. drew a parallel between berry bushes and willows on one side, human beings on the other: the former are more reliable than the humans, they have a duty to fulfil, and that is to feed the humans.

It strikes us that this description is not quite accurate: willows and grass may be food for buffaloes, but not for men. The original idea was possibly that the willows symbolized the new verdure that would provide the animals-horses, buffaloes, antelopes, and so on-with food. Unless, of course, the eagle-nest idea was basic.

6.5. The eagle. One of the rafters that serve as a "roof" carries at its top end an eagle, or eagle feathers. This rafter, which runs in an east-west direction from its anchorage in the centre pole, is usually called "the backbone", and is deeply forked. In the old days people caught an eagle (pia kwina) for each, or every second, Sun Dance. Like other Prairie and Plains tribes the Shoshoni constructed small hide-aways made from stones on mountain ridges, and caught the eagles alive there (C.S.) ${ }^{64}$. Nowadays the bird is usually replaced by its tailfeathers, or a stuffed bird is fetched. I have seen both alternatives used. When the Dance has ended the eagle, or eagle feathers, are brought back to a pine in the mountains.

Like the buffalo the eagle is a most sacred being. S.S.C. told me that he represents "the second message" in the Sun Dance legend, at the same time as he symbolizes peace and purity. "The second message" was handed down to L.S.C. by Judge Ute and begins in the following way: "Many years after the introduction of the Sun Dance [through the buffalo vision], when the first sun dancers had long been dead, a young Shoshoni had a nightly vision. It was an eagle that came flying from the place of sunset towards east, into the tipi of the sleeping young $\operatorname{man}^{65}$. The spirit said that he should make new the endurance dance." The eagle ordered some new ritual performances, prescribed that an eagle bird was appended to the "backbone" pole and that black rings should be painted on the nether part of the centre pole for the number of days the Dance should run. (Since the painting should be done by a brave warrior who at the same time recounted his war deeds this custom has become abandoned.) Finally, the eagle instructed the people to put up as many roof poles as he had tailfeathers-twelve in number-and to make whistles to be used in the dance from the bones of his shoulder wings and to use his wings as a fan in healing sick persons.

The same informant, L.S.C., remarked that the Supreme Being had selected the eagle for his second message because "he is superior to all

${ }^{64}$ The procedure is described in Wilson $108 \mathrm{ff}$. (Hidatsa Indians).

${ }_{65}$ The buffalo in the first vision arrived, on the other hand, from the rising sun, for "like the sun he gives life and food for man" (L.S.C.). 
birds, and in his flight he will soar; his body is free from impurity." (On the other hand, L.S.C. underlined that the eagle is not, like the U.S. eagle emblem, a symbol of freedom.) Before the eagle is fastened to the rafter a man chosen for the task offers a prayer in which he asks the Supreme Being to bless the people "as you have this eagle to whom you have given power to fly in the sky, where there is fresh clean air, where there is no sickness" 66 .

The eagle is the bird of peace. His feathers are used "for peaceful meeting." If two Indian groups come together, they hold up eagle feathers as a token of peace, said L.S.C. This is of course an echo of calumet and peace pipe ceremonies on the central and northern Plains. At the same time the custom conforms to conceptions of the eagle held all over North America. On the other hand, the Sun Dance eagle's association with the thunderbird is not as clearcut with the Shoshoni, as for instance, it is among the Oglala Sioux.

It seems that the symbolism of the eagle as expressed here is a reformulation of its role-known all over the northern hemisphere-as the heavenly bird (the messenger of God, or God himself) at the top of the world tree ${ }^{67}$. Such a reformulation could easily take place within the frame of the vision pattern so characteristic for the Plains Indians and for the Shoshoni. L.S.C., who was a chairman of the Sun Dance committee, had witnessed many cases where dancers had experienced visions of a spiritual eagle, groped after it with their arms and then fallen backwards or sideways, losing their consciousness. J.T. was visited in his sleep by an eagle who urged him to put up a Sun Dance. "The eagle gave me the Sun Dance." It is most probable that the so-called second message (in so far as it really contained any innovations) had a similar origin.

6.6 The flags. The forks of the centre pole are topped by two square flags. Tradition prescribes that they should be one white, the other blue. However, also other colours are possible, provided they express the opposition between light and dark. L.S.C. saw them as symbols of day and night, sky and earth ${ }^{68}$. In other words, the two branches of the tree are supposed to express the cosmic duality.

I noticed that at one Sun Dance the northern fork had a yellow and the southern a whitish flag, which does not conform to this interpretation; also, the centre pole had been painted yellow up to shoulder-height. The reason for this was a vision that the medicine-man T.R., one of the Sun

66 St. Clair Ms.

67 According to Dick Washakie eagle feathers could be fastened to the high forked branches of the centre pole (Hebard 1930, 294). Other observers have like myself seen the eagle lashed to the tip of a long rafter (Hart 8). Reports that the eagle was tied to the lower end of a rafter just over the entrance seem less trustworthy (Stafford 1938; this paper is apparently a copy of an anonymous manuscript preserved in the agency files at Fort Washakie).

${ }^{68} \mathrm{Cf}$. also St. Clair Ms. 
Dance leaders, had had. T.R. told me he was visited by one of those spirits that had instructed the people about the first Sun Dance. The spirit, that looked like a human being, approached him from the north and said, "When you put up the Sun Dance, use yellow paint. Tell the tribe that whenever they are going to have a Sun Dance to paint it yellow."69

This example shows how easily symbols may change character in the Plains area. L.S.C. was aware of this: "In the eagle vision[=the second message] people were told to make the flags green and blue, since the eagle and Our Father have their abodes in the sky. Later on, since we introduced two Sun Dances [each season], the colours have been revealed in the sponsor's vision."

6.7. The manikin. The Sun Dance doll (puêlk) is no regular feature of the modern Sun Dance. B.S.C. remembered that before about 1918 a doll was carved for each new Sun Dance by a certain man selected for the job. It was made from wood, had feathers sticking up from the back of the head, and its cheeks were decorated with the lightning sign. According to B.S.C. this wooden doll was the spirit that imparted the first instructive vision to the founder of the Sun Dance ${ }^{70}$. T.R. called the doll "the spirit of the Sun Dance" 71 , and L.S.C. said vaguely that "it represents creation."

What T.R. and L.S.C. said holds good for the present doll spirit as well, although its import is slightly different. As B.S.C. stressed, the doll used by Andrew Bazil in the 1920s was his personal medicine, and the same goes for the present doll which is in the possession of J.T. The latter puts it up when he himself, or a relative of his, dances and needs protection. It is then fixed on the west side of the centre pole, about 2 metres from the ground. It portrays a little Indian, $30 \mathrm{~cm}$ in height, made from buckskin and thus white and yellow in colour. There is a little green feather at the back of the head. The facial features are sown with a black thread, and the eyes are small black crosses. $J . T$. received this spirit in a vision. It is a "desert spirit" that helps when a person is strained, and J.T. called it "the great medicine-man that gives power in the Sun Dance." At the same time he regarded it as a link in the chain of Sun Dance dolls: he had, he said, received it from the old-timers. It connected him with his ancestor, Yellow Hand, who owned the first Sun Dance doll.

All the data presented here clearly show that the Sun Dance lodge and its parts has a cosmological symbolism. It could be easily demonstrated that also the paraphernalia of the dancers and the ritual actions before and during the Dance may express a similar symbolism. However, our special

\footnotetext{
${ }^{69}$ It should be added that the medicine-man M. Moon, active during the time between the World Wars, and mentioned in the foregoing, demanded all dancers to have yellow paint the first dancing day (information by L.S.C.).
}

${ }^{70}$ B.S.C. probably refers to the spirit of the picture revealed to Yellow Hand, cf. note 54 above.

${ }^{71}$ Cf. also Shimkin 1953, 418, 441 n. 48. 
object of analysis has been the cultic lodge, and its symbolic language is unequivocal.

Compared with the preceding account of the meaning of the Sun Dance the analysis of cult symbolism brings out more readily the ulterior import of the Dance. Some statements on the meaning of the Dance seem to get along with the symbolic interpretation of the Dancing lodge, others are mixed up with the particular motives for arranging a Dance.

In addition, there is the confusion caused by the application of Christian symbolism.

\section{Christian reinterpretation}

The main lines of Christian reinterpretation of the Sun Dance were presented in an earlier paper ${ }^{72}$. Here I shall restrict the account to the Christian symbolism in the Sun Dance lodge, but at the same time present some more details.

One strong difference from the foregoing description will immediately catch the attention: whereas there was a fair consensus about traditional symbolism, there is not the same agreement among informants as to the Christian interpretation. Indeed, one and the same individual may even suggest different Christian symbols to denote one and the same cultic phenomenon. Thus, L.S.C. identified the centre pole as the cross, Christ and the path through life. The same persons who ascribe a traditional tribal symbolism to the dancing lodge will, as an addition to this, and as an afterthought, present a Christian interpretation. This attitude fits in with my observations of the Shoshoni tendency to conceive alternating religious configurations $s^{73}$. At the same time it bears testimony that the Christian symbolism is imposed upon the Sun Dance and does not constitute its ideological premisses.

The Christian reinterpretation represents a process that certainly took its beginning about 1890 but, since that date, has gone on incessantly. As an example could be mentioned the case of L.S.C. When studying to become a catechist in the Episcopal church this faithful guardian of Shoshoni traditions found out that Christ and his apostles were represented in the upright main poles of the Sun Dance lodge. After 1945 he and his companions made these findings public in the Shoshoni Sun Dance camp.

Here are some examples of Christian reinterpretation.

7.1. The Dance lodge is, according to Y.S., the grave of Christ. "When you get out of it you go to a renewed life, like Christ." An imaginative Idaho Shoshoni (J.R., belonging to the hukandika group ${ }^{74}$ ) told me that the Dance symbolizes how Jesus hung on the cross for three days, and then

${ }^{72}$ Cf. Hultkrantz 1969, $36 \mathrm{ff}$.

${ }^{73}$ Cf. Hultkrantz 1969, $26 \mathrm{f}$, and literature

74 Cf. Hultkrantz 1975, $139 \mathrm{f}$. referred to there. 
was taken down. He also said that the rafters of the lodge stand for the apostles and the brush intertwined in the "wall" for the innumerable members of the people.

7.2. The centre pole is in most cases Christ or, as he is designed in this connection, "our brother". L.S.C. explained that by its fork the centre pole forms the sign for brother in the sign language: two fingers drawn out of the mouth into the $\mathrm{air}^{75}$. Another interpretation is that the centre pole represents the cross of Christ, for the bunch of willows forms the arms of the cross (L.S.C.) ${ }^{76}$. Finally it is our path through life, a conception which may have Christian patterning, as noted in the foregoing.

In contradistinction to traditional symbolism also other poles may have a symbolic value in Christian reinterpretation. The twelve main corner poles are designated the apostles of Christ. Also the twelve rafters are so called ("Jesus' brothers"). One informant, J.T., agreed with the first interpretation, but at the same time he suggested that the poles standing directly north and south of the centre pole represent the robbers of Golgotha. L.S.C. who was not very sympathetic to J.T. denied the truth of this interpretation.

7.3. The buffalo head was identified as Christ by T.W. and G.W., father and son. I did not find that other Shoshoni applied a Christian interpretation in this case. See however the paragraph on the eagle, below.

7.4. The willows may be seen as part of the cross (see above). One of Shimkin's informants held that the willows symbolize the Holy Water that Christ made in the mountains ${ }^{77}$.

7.5. The eagle, the "second messenger" according to L.S.C., might be a representative of the New Testament (just as the buffalo, in a vague sense, might be the Old Testament) in L.S.C.'s opinion. It was his thought that the eagle vision was sent at the birth of Christ. The rafter that the eagle is resting on is, said the same informant, the Judas pole, for it is the only rafter that is forked. L.S.C. is referring here to the sign language where "talking with a forked tongue" stands for lying ${ }^{78}$. Judas was of course a lyer, hence the association.

7.6. There is to my knowledge no Christian symbolism attached to the flags.

7.7. The doll is a symbol of Jesus. L.S.C. admitted this interpretation although he rightly suspected that the doll then (1948) in use was made by J.T.'s wife.

\section{Conclusions}

It is now possible to arrive at some valid conclusions concerning the original idea and later religious change of the Shoshoni Sun Dance. The analysis

${ }^{75}$ Cf. Clark 82.

76 The missionaries translated "cross" into

77 Cf. Shimkin 1953, 441 .

Shoshoni "branched tree", cf. Roberts 13.

78 Cf. Clark 234. 
of the symbolism of the lodge itself provides us with means to make this evaluation, and it also helps us to judge Jorgensen's theory that the modern Dance is a revitalization movement.

First of all it is obvious that the Shoshoni Sun Dance lodge, like many other Sun Dance lodges, evinces a symbolism that stresses its character of being a renewal ceremony with cosmological implications ${ }^{79}$. The symbolism of the cultic lodge brings out that, whatever the motives for the arrangement of the Sun Dance, its basic ideology must once have been largely identical with that of the modelling western Algonkian tribes (Cheyenne, Arapaho). This is an important statement. It furthermore generates the hypothesis that the original idea behind all the older Sun Dance performances among the Plains tribes had the same contents.

We may here pause and make some other inferences. It seems reasonable to presuppose that the old Shoshoni way of life and its values were expressed in the original thanksgiving ceremony, the "Father Dance". When, however, this hunting and gathering existence was superimposed by the more nomadic and colourful Plains culture-with its roots in highly developed cultures farther east-the Father Dance was replaced by the Sun Dance in importance and slowly dwindled away. The Sun Dance embodied the ideas and values of the bison-hunting, warlike Plains tribes ${ }^{80}$. It also contained the cosmogonic and cosmological symbolism of the eastern cultures. The deep impact of the Sun Dance in Shoshoni culture is obvious to anyone studying their traditional religion. There is even a tale of rats dancing a Sun Dance in a buffalo skull, and J.T. told me he had seen one morning bears perform the Sun Dance at a creek ${ }^{81}$ !

Our second conclusion is that the Christian reinterpretation of the symbolism of the Sun Dance lodge is accidental rather than integrative. From the outset it represented a kind of reconciliation between Christian and Shoshoni religions. The Christian symbolism was an additive element in the Sun Dance designed to make the latter more acceptable to Christian missionaries. We must remember that from the 1880 s onwards missionaries and superintendents made efforts to prohibit the Plains Sun Dances, and some clergymen on the Wind River Reservation succeeded in closing the ceremony for a number of years. The religious liberalism initiated by the Government after 1934, and the proclamation of the free exertion of American Indian religions in 1978, have of course made such reasons for a Christian reinterpretation increasingly superfluous. In later years the Christian symbolism has served as an alibi for the participation in the Dance by Indians with a predominating Christian faith. There is reason to believe that

\footnotetext{
${ }^{79}$ Wissler's statement, that Plains Indian art "is strongly geometric, but as a whole, not symbolic" (Wissler 1950, 222), is apparently erroneous. Cf. Wissler 1941, $132 \mathrm{ff}$., in particular 137.
}

${ }^{80}$ Cf. Hultkrantz 1949, 153.

${ }^{81}$ Cf. Hultkrantz 1970, 72 f. 
with the new religious situation the Christian reinterpretation will gradually weaken.

The third conclusion we can draw is that Jorgensen's view of the Shoshoni Sun Dance as a redemptive movement is misleading. It is true that health and curing of disease are prominent issues in today's sun dancing. However, this is not a testimony of a restructuring of the Dance, its transformation into a new religion. It only means that one of the moments of the Sun Dance mystery, the renewal of life and health, has received a central position in a daily existence no longer marked by anxieties for the survival of the tribe and the world, but by worries of the individual's fate in a multidimensional human situation.

Finally, a comparison with the modern Crow Sun Dance is rewarding. The Crow, situated in southwestern Montana, earlier had a Sun Dance which, however, on account of its close association with military life disappeared with the cessation of warfare in the $1870 \mathrm{~s}^{82}$. In 1941 the Shoshoni J.T. introduced the Shoshoni form of the Sun Dance among the Crow ${ }^{83}$. The Crow Dance thus shares the peculiar traits of the Shoshoni Dance, such as the concentration on health and curing, and the back-and-forth dancing ${ }^{84}$. Recently the symbolism of the Crow Sun Dance lodge has been studied by Mr. F. Miller, U.S.A. ${ }^{85}$ He was not able to find any clearcut Crow statements on the renewal-of-the-world motif ${ }^{86}$, but the cosmic symbolism seems clear.

Miller states that to the Crow the centre pole and the circle of forked poles surrounding it are "symbols of the cosmos as a whole." The shape of the lodge provides "a visual image of the cosmos of the Crow." The centre pole is the centre of the sacred space of the lodge, and the place where power is concentrated. One of its forks represents heaven, the other earth, and their merging at the fork signifies the unity of these cosmic principles. At the base of the pole cigarettes are collected which have been smoked in prayer by dancers. "With these objects the center pole becomes

${ }^{82}$ Cf. Lowie 1915 a, 5.

${ }^{83} \mathrm{Cf}$. Voget $634 \mathrm{ff}$.

${ }^{84}$ For some reasons unknown to me Jorgensen identifies the "new" Sun Dance as a particular expression of the aspirations of the Numic-speaking peoples. The Crow are not mentioned. In this way he can easier keep the new Dance apart from the "true" Plains ceremony.

${ }_{85}$ Cf. Miller Ms.

${ }^{86}$ In a letter to me (May 10, 1978) Miller states that he was surprised by its absence. "I probed for it with a number of Crow friends, but in vain. It is all the more unusual in that the Crow do feel that the performance of the Sun Dance has a revitalizing effect on the community. I spoke with a num- ber of dancers who said that one of the main reasons for their participation was the promotion of the general welfare of the Crow for the coming year. I also encountered a general, but rather vague, understanding that there is some danger, not clearly or specifically defined, in allowing a summer to go by without performing a Sun Dance. This in spite of the decidedly non-cyclical nature of the Sun Dance ritual itself [...]. The emphasis seems to be on the present moment and the potential for future events, rather than upon a primordial past which must be re-created and renewed annually. Hence, the perception of the revitalization of the community without the attendant notion, which we could expect, of re-creation and renewal of the cosmic order." 
a representation both of the powers to whom the Dance is directed and of the silent and verbal offerings which invite them to sanctify the Lodge by their presence."

The buffalo head, the eagle and the buckskin doll are appended to or near the centre pole as they are in the Shoshoni Dance. They have here the same symbolic implications. The eagle is said to be very closely associated with the Supreme Being.

The cosmic symbolism of the Crow Sun Dance, an offshoot of the modern Shoshoni Sun Dance, is thus most evident. Perhaps it partly derives from the old Crow Dance, although the hiatus of 67 years between the two Dance forms seems to preclude this possibility. The parallels with Shoshoni symbolism are so intimate that the latter has probably been the chief source of inspiration. It seems however that in both Sun Dances the basic ideological structure to which the cosmic symbolism refers has fallen away as a conscious thought: the idea of the re-creation of the world. Among the Shoshoni we have no origin myth to substantiate this idea ${ }^{87}$. The origin legend, instanced in the foregoing, sheds no light on the cosmological interpretation. What remains of the latter is the symbolism, and its language is clear.

\section{Bibliography}

\section{Unpublished sources}

BERKELEY

University of California,

Shimkin, D., 1939. Some interactions of culture, needs and personalities among the Wind River Shoshone. Diss.

\section{LARAMIE}

University of Wyoming-Archives,

Thompson, J., In Old Wyoming.

FORT WASHAKIE

Wind River agency files,

[Anonymous] The Indian Sundance.

St. Clair, L., The so-called Shoshone Sundance, which the Shoshones call: Da-g-oo Wi-n-o-de.

Various letters; death records.

LIDINGÖ

Private archive- $\AA$. Hultkrantz,

Hultkrantz, $\AA$., Wind River Shoshoni field notes.

Miller, F., letter to $\AA$. Hultkrantz, May 10,1978

Roberts, Marion, The Shoshone Sun-Dance.

Philadelphia

Temple University,

Miller, F., 1977, The Crow Sun Dance lodge: form, process, and geometry in the creation of sacred space.

${ }^{87}$ Cf. Hultkrantz 1960, 565; id. 1972, 348 f. 


\section{Published sources}

AA American anthropologist

HR History of religions

APNH Anthropological papers of the American museum of national history

Aberle, D., 1966, The Peyote religion among the Navaho. Viking Fund publications in anthropology, 42. New York.

Allen, W., 1913, The sheep eaters. New York.

Brackett, A., 1880, The Shoshonis, or Snake Indians, their religion, superstitions, and manners. Annual report of the Smithsonian Institution for 1879. Washington.

Clark, W., 1885, The Indian sign language. Philadelphia.

Dorsey, G., 1903, The Arapaho Sun Dance. Field Columbian Museum, Anthropological series, 4. Chicago.

Eggan, F., 1954, Social anthropology and the method of controlled comparison. $A A, 56$.

Eliade, M., 1971, The myth of the eternal return. Princeton.

Fremont, 1952, Fremont county and its communities. Ed. C. Jayne. Laramie.

Hart, S., \& Carlson, V., 1948, We saw the Sun Dance. Concord.

Hebard, G., 1930, Washakie. Cleveland.

- 1933, Sacajawea. Glendale.

Hoebel, E., 1935, The Sun Dance of the Hekandika Shoshone. AA, 37.

Hultkrantz, $\AA ., 1949$, Kulturbildningen hos Wyomings Shoshoni-indianer. Ymer 69.

- 1960, Religious aspects of the Wind River Shoshoni folk literature. Culture in History, ed. S. Diamond. New York.

- 1961, The Masters of the Animals among the Wind River Shoshoni. Ethnos 26.

- 1965, The study of North American Indian religion. Temenos, 1.

- 1967, Historical approaches in American ethnology. Ethnologia Europaea 1.

- 1967 a, North American Indian religion in the history of research, 3. HR 7.

- 1968, Yellow Hand, chief and medicine-man among the Eastern Shoshoni. Proceedings of the 38th International congress of Americanists, 2. Munich.

- 1969, Pagan and Christian elements in the religious syncretism among the Shoshoni Indians of Wyoming. Syncretism, ed. S. Hartman. Scripta Instituti Donneriani Aboensis, 3.

- 1970, Attitudes to animals in Shoshoni Indian religion. Studies in comparative religion, 4 . Bedfont.

- $1970 \mathrm{a}$, The source literature on the "Tukudika" Indians in Wyoming: facts and fancies. Languages and cultures of Western North America, ed. E. Swanson, Jr. Pocatello.

- 1972, An ideological dichotomy: myths and folk beliefs among the Shoshoni Indians of Wyoming. $H R, 11$.

- 1973, Prairie and Plains Indians. Iconography of religions, 10. Leiden.

- 1975, Haivodika, an acculturated Shoshoni group in Wyoming. Zeitschrift für Ethnologie, 100.

- s.a., Mythology and Religious Concepts. Handbook of the North American Indians, 11. Washington (in press).

Jones, W., 1875, Report upon the reconnaissance of Northwestern Wyoming [...] in the summer of 1873 . Washington.

Jorgensen, J., 1972, The Sun Dance religion: power for the powerless. Chicago.

Life, 1931, The life and adventures of James P. Beckwourth. Ed. T. Bonner. New York.

Lowie, R., 1909, The Northern Shoshone. APNH, 2.

- 1915, Dances and societies of the Plains Shoshone. APNH, 11.

- 1915 a, The Sun Dance of the Crow Indians. APNH, 16. 
- 1919, The Sun Dance of the Shoshoni, Ute, and Hidatsa. APNH, 16.

- 1954, Indians of the Plains. New York.

Müller, W., 1956, Die Religionen der Waldlandindianer Nordamerikas. Berlin.

- 1970, Glauben und Denken der Sioux. Berlin.

Murphy, R. and Y., 1960, Shoshone-Bannock subsistence and society. Anthropological records, 16. Berkeley.

Olden, S., 1923, Shoshone folk lore. Milwaukee.

Roberts, J., 1925, Indians of the Rockies and the Pacific Coast: Shoshone and Arapaho, Wind River reservation. Indian tribes and missions, 4. The Church in story and pageant, 8 . Hartford.

Schmidt, W., 1929, Der Ursprung der Gottesidee, 2. Münster.

Shimkin, D., 1953, The Wind River Shoshone Sun Dance. Bureau of American ethnology. Bulletin 151. Anthropological papers 41. Washington.

Spier, L., 1921, The Sun Dance of the Plains Indians: its development and diffusion. APNH, 16.

Stafford, C., 1938, Shoshone Indian Sun Dance. Wyoming wild life, 3.

Underhill, R., 1965, Red man's religion. Chicago.

Voget, F., 1948, Individual motivation in the diffusion of the Wind River Shoshone Sun-dance to the Crow Indians. $A A, 50$.

Wilson, G., 1928, Hidats a eagle trapping. APNH, 30.

Wissler, C., 1941, North American Indians of the Plains. New York.

- 1950, The American Indian. New York. 